\title{
PATH FINDER STRATEGY RADAR
}

\author{
Prof. Manoj Joshi \\ Amity Business School, Amity University, Lucknow Campus, India \\ E-mails: manoj.joshi.m@gmail.com (corresponding author)
}

Received January 2013; accepted April 2013

\begin{abstract}
Purpose- The purpose of this research is to define and craft a "Path Finder Strategy" that can be adopted by firms, while entering into different markets with differentiated products. This conceptual yet a research paper covers an in-depth knowledge relating to devising a strategic 'radar zone' and assist in ascertaining whether a firm is product driven, market driven or customer driven (type of the firm).

Design/methodology/approach- The learning from international evidences connected with the "type of the firm" has been extended to many firms operating in India. An exhaustive list of firms was studied operating in India and five firms were picked that strongly reflected the drivers to strategy. Detailed case study followed by analysis was undertaken, while each driver to strategy was discovered that associated with a type of firm.
\end{abstract}

Findings- There are unique drivers to strategy befitting each type of firm identified under product driven, customer driven and market driven firm. Thus, a "Path Finder Strategy" can be crafted for each type of firm.

Research limitations/implications- There is a scope for discovering and connecting additional drivers' to strategy associated with each type of firm. The research is confined to Indian Territory and firms operating within India, however, if global firms operating from different geographies could be studied for a more universal learning.

Practical implications- Firm falling under a typical type of firm and thereby exhibiting a distinctive characteristics will have a unique "path finder strategy radar" based upon the industry it represents. Hence, firms can identify where the firms strategy is and should be to steer in the right direction.

Originality/value- The research is based on field study and research at the primary and secondary level of investigations.

\section{Conceptual paper}

Keywords: Path finder strategy, Strategy radar, Innovation, Competitive advantage, Dynamic capability.

Reference to this paper should be made as follows: Joshi, M (2013). "Path Finder Strategy Radar", Journal of Entrepreneurship, Business and Economics, Vol. 1 No. 1/2, pp. 17-34. 


\section{Introduction}

Strategy is an integrated and coordinated set of commitments and actions designed to utilize core competencies (Prahalad and Hamel, 1990) and gain competitive advantage (Hitt et al, 2006). The firm decides the course based on the exogenous and endogenous factors, which can either be as an endowment or impediment to its existence. Core competence (Prahalad and Hamel, 1990), combines resources and capabilities that a firm possesses and converts into a competitive advantage to the firm over its rivals'. Thus a firm manoeuvres though uncertainties, challenges and barriers to its existence and traces its path to a profitable existence, which is the very fundamental cause for a firm to exist. It is usually advised to choose a strategy oriented to the firms' competence, however, capability augmentation can be an added perspective during the firms' life cycle, which will drive its performance.

Strategic management mainly considers firms' internal and external environments, imperative for long-term planning (Drejer, 2002; Leontiades, 1982). The firms' internal environments comprise competencies related to manufacturing that are more controllable by management (Miller, 1982). This relates to the firms' supply chain, which include customers, suppliers, competitors, creditors, associations and unions. The external environment, which is more uncontrollable, includes economic, technological, political and legal, and socio-cultural contexts (Wheelen and Hunger, 1983). According to Drejer (2002), changes in external environment spark developments in the area of strategic Management. Ansoff's (1965) was responsible for contributing on SWOT concept, while Shapiro (1989), Yavitz and Newman (1982), Porter (1980, 1985) introduced the concept of product-market based view. This was followed by views on resource-based and dynamic capability (Teece et al., 1997; Teece, 1984; Hamel and Prahalad, 1994; Prahalad and Hamel, 1990; Ghemawat, P. 1991; Penrose, E.T., 1959).

Primarily, the product-market-based views lay importance on competition capabilities (Fowler and Hope, 2007) and marketing (Corbett and Van Wassenhove, 1993). Here, the strategic focal point is on obtaining market power and competitive advantage and secure it through positioning by building entry barriers to the firm's market segment (Porter, 1980, 1985). Strategies that are based on this concept lay focus on attaining competitive advantage over rivals. At times, for positioning themselves, firms compete based on game theory for analyzing strategic conflicts that characterize the product-market-based structure (Teece et al., 1997; Shapiro, 1989; Brandenburger, A.M., and Nalebuff, B.J. 1995). According to Hart (1995), the competitive advantage in the framework of resource based view is based upon difficulty to imitate internal capabilities, while Ward and Duray (2000), talk about how firms' resources are to put to best use towards firm performance.

Teece et al. (1997) and Teece (1998) relay importance on firms' innova- 
tions and differentiations that are based on unique tangible (i.e. technologies) and intangible (e.g. intellectual capital) assets. Therefore, such tangible and intangible competencies collectively form the foundation for differentiating strategies and hence the competitive advantage (Eisenhardt and Martin, 2000). Teece et al. (1997) furthered upon the resource-based framework and introduced the dynamic capability view. In the dynamic capability framework, attaining competitive advantages engages the abilities on the management's part to adjust, combine, discontinue or add to firms' extant resources (Eisenhardt and Martin, 2000). The dynamic capability view also proposes that path dependency (i.e. firms' inherited or evolutionary) is another key component in determining the success of future strategies for competitive advantage (Teece et al., 1997). According to Brown and Blackmon (2005), in dynamic competing environments, successful strategies are created by managements' abilities to explore all strategy frameworks and to develop a strategic character, while Mintzberg, H. (1978) highlights the role of the firm's past.

Firms adopt strategies suiting their purpose; however they are driven by the very basic need of customer and market expansion. Each firm is engaged in a battle to outsmart its competitor by creating new products, orienting more towards customers, mining unexplored markets while staying ahead in the race to emerge as leader. As a result, certain firms stay flexible in their orientation towards products, customers and markets, the key ingredients in the process of crafting a strategy. The magic of hypnotising customer, seducing or intoxicating, followed by addiction is what most firms are engaged into.

\section{What Successful Firms follow?}

Strategy is something that is imposed on the company, and the chief executive is who imposes it (Kay, John, 1995). A firm must clearly identify and define its nature of business, the "core business". Hence, based on its core competence the product/services will get defined followed by its boundaries. The gaps will have to be followed with each learning experience through capability and capacity augmentation. Successful firms trace the same path while building a strong architecture and reputation around themselves. Each strategic asset they possess emerges as a stealth weapon followed by their innovativeness to add to their distinctive capability. The business relationship is well streamlined through cooperation, coordination and contracts. The markets are well defined as they progress to lead into home markets as well as storm the new ones through mergers and acquisition. Each process adds to their competitive advantage.

\section{Innovation and Strategy Nexus}

Rogers (1983) defines innovation as an idea, practice or object that is perceived as new by individuals or units that adopt it. Some researchers define innovation as 
'the adoption of an internally generated device, system, policy, program, process, product or service that is novel to the adopting enterprise'. Thus according to Oster (1994), the highly innovative and entrepreneurial firms require entrepreneurial leaders who successfully manage the innovation process to discover or create and then exploit opportunities. Herbig (1994) comments about the high order innovations that basically create new industries, products or markets.

"Strategic Innovation" is imperative to everlasting impact on the survival of the enterprise engaged in true level of competitive entrepreneurship. These strategic innovations may emanate in the field of new technology, like information technology. They can emerge from the discovery of new and more convenient location, like in retailing. They can come in the form of new raw materials or discovery of new sources of raw material, like fiber optics or alloys, or new oil and gas fields. They can be in the form of product or services like new credit cards or mobile phones. They can come from new forms of enterprises like strategic alliances, flat enterprises, the ambidextrous enterprises that can manage contradictions like short-term vs. long-term, control vs. autonomy. They can come in marketing practices like customer management relations and in boundary relationship management. In fact, the scope and possibilities for innovations are infinite and difficult to be concise and build boundaries (Joshi, 2010a).

According to Prahlad \& Krishnan (2008), business processes will become the enablers of innovation. Some firms will emerge as game-changer (Lafley \& Charan, 2008), defined as a visionary strategists who alters the game his business plays or conceives an entirely new game. Innovation impacts the bottom line of the organization and it applies to products and services as well (Joshi, 2010b).

Thus, most firms competing to exist will have to constantly engage in creating value to the customers and the markets it serves, driven by the vortex and velocity of innovation as vital to its sustainability.

\section{Concept of Product Driven, Market Driven and Customer Driven Firm}

The fundamental reason for a firm to exist is maximise profits. It is the strategic combination of a stealth product, hungry customer and a segmented market, well timed that makes the difference from a successful firm to a not so successful firm. The firms vacillate in seducing the customer for its profitable existence.

Primarily a firm is seeded or is born around key product/service to an intended customer for a particular market, and it is from here where the firm leads a directional approach. During its existence, the firm initiates its operation based on the core competence it has, based on requirements. This process termed as capability augmentation or capacity augmentation transverses the firm from translating 
opportunities into gains. These gains can be measured in terms of ideas generated, new products launched, research and development, customer satisfaction, increase in customer base from the same market, new customers' acquired, new markets' explored and profitability.

A product driven firm has a strong orientation in conceiving new ideas, developing technologies, new products and innovation as key drivers to differentiation from its competitors. The customer driven firm is strongly oriented towards the brand expectations', brand positioning, customer differentiation, the purchasing power, customers' delight and customer relationship management. However, a market driven firm visualises the market potential, product competitiveness, business environment and market orientation.

\section{Product Driven Firm}

A Product Driven Firm will initially attract customers who shall then orient themselves to the offerings by the company, thus slowly forming into a market (figure 1a: Product->Customer->Market). This phenomenon is evident in high technology driven innovative firms. It is the technology absorption capacity by the customers that creates newer markets. In the long run, some of these firms are close to saturation of technology for a particular application area and a switch over their customer focus to market(s) (figure 1b: Product->Market->Customer). Customers become subset of the market. Thus, a product driven firm is engaged in either producing products corresponding to the common requirements of the customer or largely by the market. 
Figure 1a: A Product driven firm, which acquires \& creates a customer(s) and then creates market(s)- Product->Customer->Market

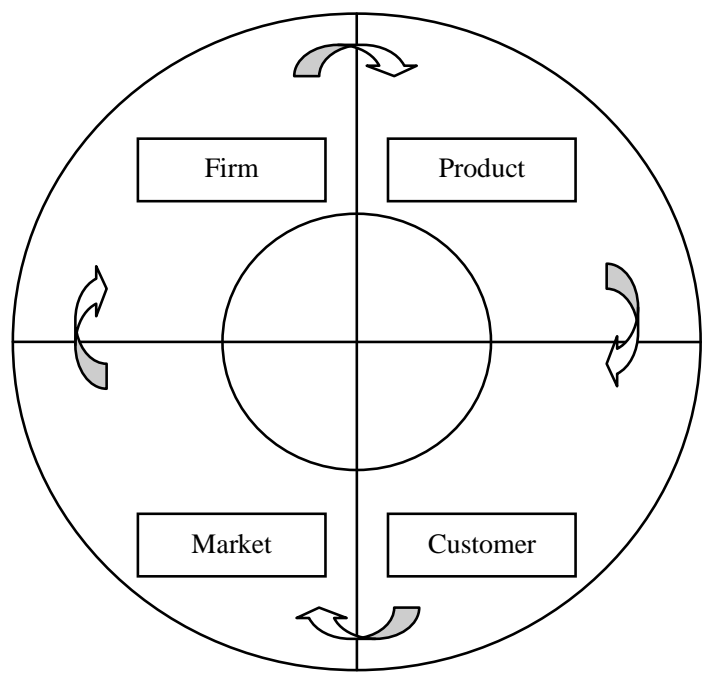

Figure 1b: A Product driven firm, which creates a market(s) and then acquires customer(s) - Product->Market->Customer

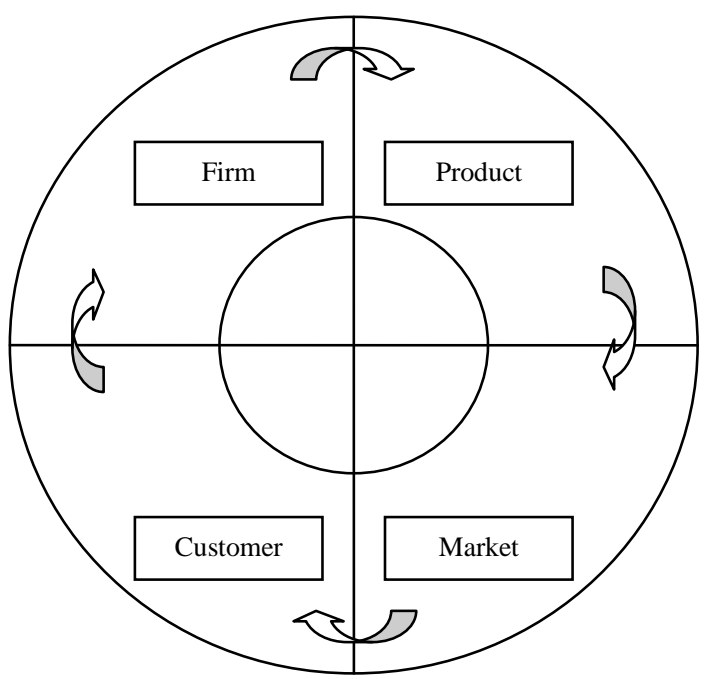




\section{Customer Driven Firm}

A customer driven firm produces exclusively, based on requirements by the customer that shall henceforth create its own market (figure 2a: Customer->Product$>$ Market). Such firms are strongly customer oriented. They may principally address the niche markets. At times certain customer driven firms produce products for a group of identified markets first and then orient their products based on the market need (figure 2b: Customer->Market->Product).

Figure 2a: A Customer driven firm, which creates product and then acquires product(s)- Customer->Product->Market

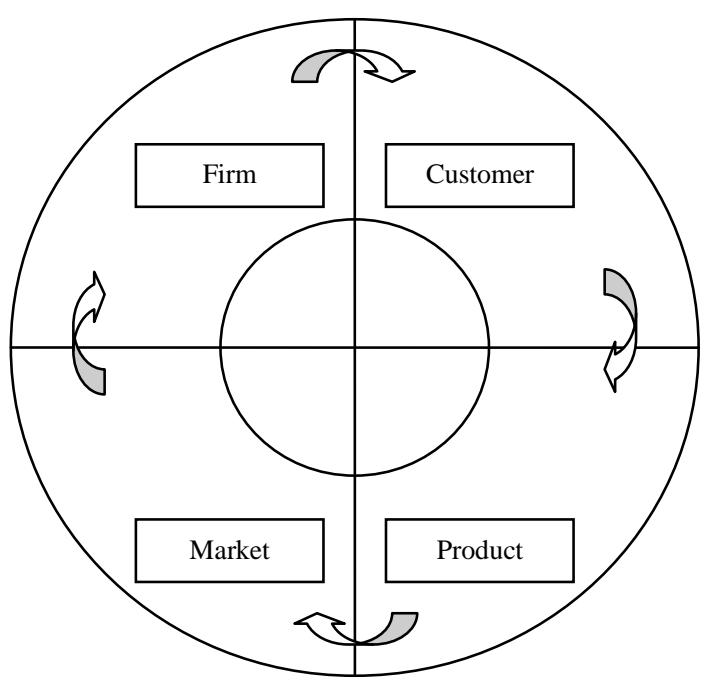


Figure 2b: A Customer driven firm, which acquires market(s) and then creates product(s) - Customer->Market->Product

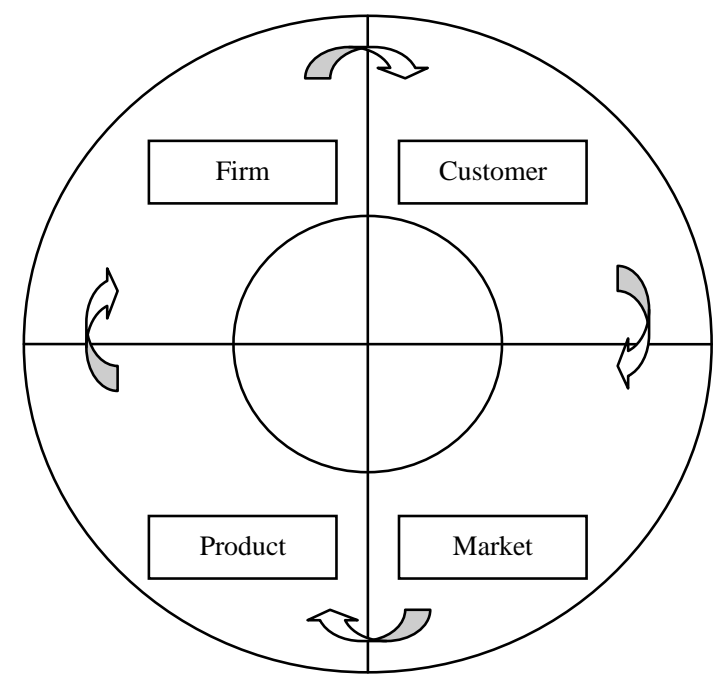

\section{Market Driven Firm}

A market driven firm is majorly connected in segmenting the customers' based on its typical requirements' and needs'. The market leads to product development, which then decides its customers (figure 3a: Market->Product->Customer). The products emerge as a strong brand and drive the customer needs. However, few of these market driven firms initiate in identifying its customers and then develop products for them (figure 3b: Market->Customer->Product). This subset orientation is evident for firms that constantly engage in customizing products' once the market is established. 
Figure 3a: A Market driven firm, which creates a product(s) and then acquires customer(s) -Market->Product->Customer

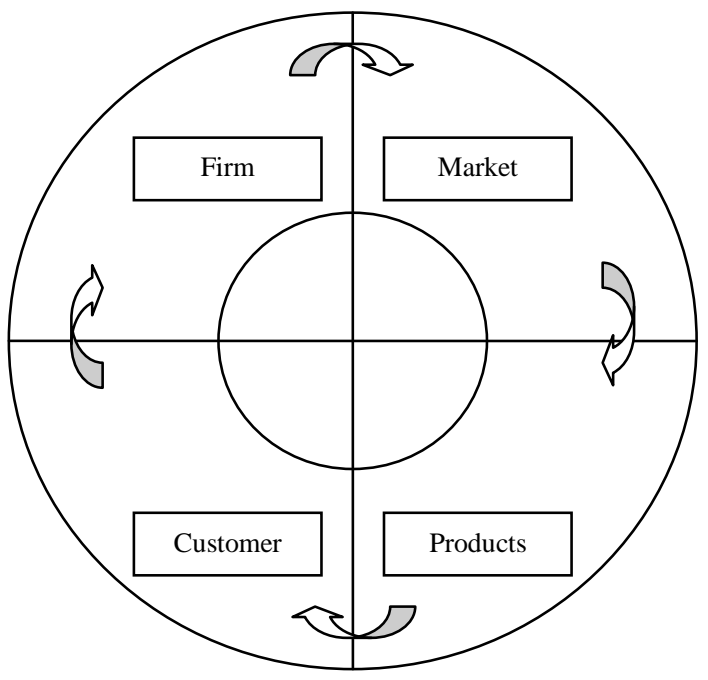

Figure 3b: A Market driven firm, which acquires customer(s) and then creates product(s)- Market->Customer->Product

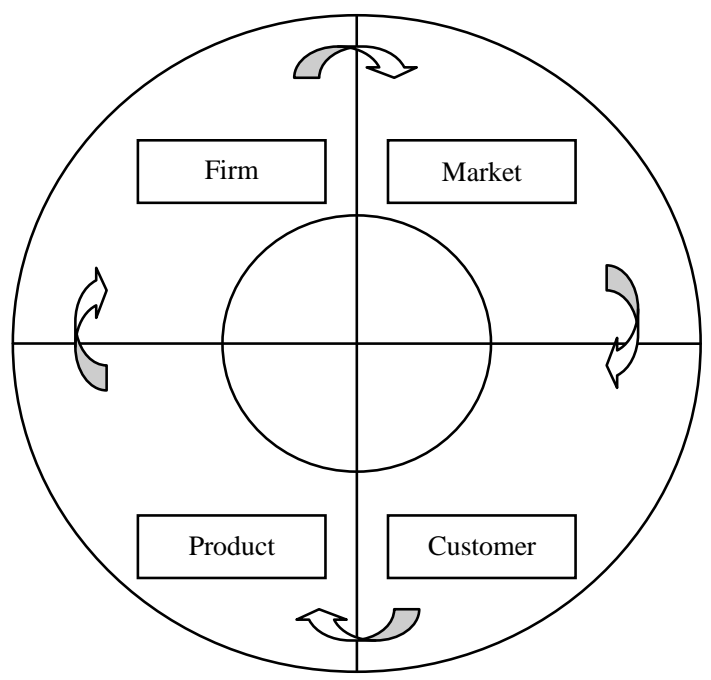


Thus, we can visualise that each successful firm intends to maximise its gain based on the orientation. However, it is difficult to quantify whether a firm from a particular industry shall follow a specified route and define its path.

\section{Global Evidences and Learning}

According to "Innovation 2009, Making Hard Decisions in the Downturn", a BCG Senior Management Survey (Andrew et al, 2009), the top 50 most innovative companies were discovered as voted by surveyors. The parameters included:

Is the company employing innovative operational processes that give it an advantage?

Is the company's business model for revenue stream new and differentiated?

Has the company created unique customer experiences' that create loyalty?

Has the company developed breakthrough products?

Has the company developed breakthrough services?

After establishing a deeper understanding on these firms', it was discovered that the firms exhibited different orientations from being firm a product driven, a customer driven or market driven firm. Based on this list of prominent International firms, certain common characteristics were discovered from the research conducted. The firms were hence classified under Table 1 as product driven firms, Table 2 as customer driven firms and Table 3 as Market driven firms.

Table 1: Product Driven Firms: Is the innovative Firm Product driven?

\begin{tabular}{|l|l|l|}
\hline S. No & $\begin{array}{l}\text { Product driven Innova- } \\
\text { tive firm (Breakthrough } \\
\text { Products) }\end{array}$ & Industry \\
\hline 1 & Apple & Technology and telecommunications \\
\hline 2 & Nintendo & Technology and telecommunications \\
\hline 3 & $\begin{array}{l}\text { Hewlett-Packard Devel- } \\
\text { opment Company }\end{array}$ & Technology and telecommunications \\
\hline 4 & Research in Motion & Technology and telecommunications \\
\hline 5 & Nokia Corporation & Industrial goods and manufacturing \\
\hline 6 & Tata group & Technology and telecommunications \\
\hline 7 & Sony Corporation & Technology and telecommunications \\
\hline 8 & Samsung electronics & Automotive and motor vehicle \\
\hline 9 & Honda Motor Company &
\end{tabular}




\begin{tabular}{|l|l|l|}
\hline 10 & AT\&T & Technology and telecommunications \\
\hline 11 & LG electronics & Consumer Products \\
\hline 12 & Daimler & Automotive and motor vehicle \\
\hline 13 & Ford Motor Company & Automotive and motor vehicle \\
\hline 14 & Nestle & Consumer Products \\
\hline 15 & $3 \mathrm{M}$ & Industrial goods and manufacturing \\
\hline 16 & Nike & Consumer Products \\
\hline 17 & Fiat Automobiles & Automotive and motor vehicle \\
\hline
\end{tabular}

Table 2: Customer Driven Firms:Is the innovative Firm Customer driven?

\begin{tabular}{|l|l|l|}
\hline S. No & $\begin{array}{l}\text { Customer driven Innova- } \\
\text { tive firm (Unique custom- } \\
\text { er experiences) }\end{array}$ & Industry \\
\hline 1 & Google & Technology and telecommunications \\
\hline 2 & Amazon.com & Retail \\
\hline 3 & Volkswagen & Automotive and motor vehicle \\
\hline 4 & McDonalds & Consumer Products \\
\hline 5 & BMW group & Automotive and motor vehicle \\
\hline 6 & The Walt Disney company & Entertainment and media \\
\hline 7 & The Coca Cola Company & Consumer Products \\
\hline 8 & Verizon Communications & Technology and telecommunications \\
\hline 9 & Virgin Group & Travel, tourism, and hospitality \\
\hline 10 & Facebook & Entertainment and media \\
\hline 11 & Johnson \& Johnson & $\begin{array}{l}\text { Pharmaceuticals, biotechnology and health } \\
\text { care }\end{array}$ \\
\hline 12 & Southwest Airlines & Travel, tourism, and hospitality \\
\hline & & \\
\hline
\end{tabular}

Table 3: Market Driven Firms: Is the innovative Firm Market driven?

\begin{tabular}{|l|l|l|}
\hline S. No & $\begin{array}{l}\text { Market driven Innovative } \\
\text { firm (Innovative processes / } \\
\text { New \& Differentiated busi- } \\
\text { ness model) }\end{array}$ & Industry \\
\hline 1 & Toyota Motor Corporation & Automotive and motor vehicle \\
\hline 2 & Microsoft Corporation & Technology and telecommunications \\
\hline 3 & IBM Corporation & Technology and telecommunications \\
\hline 4 & Wal-mart Stores & Retail \\
\hline 5 & Proctor \& Gamble & Consumer Products \\
\hline
\end{tabular}




\begin{tabular}{|l|l|l|}
6 & Reliance Industries & Energy \\
\hline 7 & Infosys Technologies Limited & Technology and telecommunications \\
\hline 8 & Telefonica & Technology and telecommunications \\
\hline 9 & Cisco System & Technology and telecommunications \\
\hline 10 & Intel Corporation & Technology and telecommunications \\
\hline 11 & Arcelor Mittal & Industrial goods and manufacturing \\
\hline 12 & HSBC Group & Financial services \\
\hline 13 & Exxon Mobil Corporation & Energy \\
\hline 14 & Royal Dutch shell & Energy \\
\hline
\end{tabular}

\section{"Path Finder Strategy": Conceptualising and Defining}

"Path Finder Strategy" can be defined as a combination of parameters based on product, customer or market orientation that a firm chooses to deploy, evaluate, measure and execute, while relating the cause and effect, thereof, to each of them. These drivers in the long term should create a competitive edge over its rivals'.

\section{Drivers to Strategy associated to Path Finder Strategy}

After extensive study and observations it was found that there existed different drivers associated with each type of firm (product, customer and market) and thus classified in Table 4.

Table 4: Drivers to Strategy associated to path finder strategy

\begin{tabular}{|c|c|}
\hline Nature of firm & Drivers to Strategy \\
\hline $\begin{array}{l}\text { Product driven firm } \\
\text { (Q2) }\end{array}$ & $\begin{array}{ll}\text { - } & \text { Innovation } \\
\text { - } & \text { Integration of technology } \\
\text { - } & \text { Technology acceptability \& adaptability } \\
\text { - } & \text { Product pricing } \\
\text { - } & \text { Product segmentation } \\
\text { - } & \text { Product differentiation } \\
\text { - } & \text { Product positioning } \\
\text { - } & \text { Brand trust } \\
\text { - } & \text { Zero advertising cost } \\
\text { - } & \text { Product after sales services } \\
\end{array}$ \\
\hline $\begin{array}{l}\text { Customer driven firm } \\
\text { (Q3) }\end{array}$ & $\begin{array}{ll}\text { - } & \text { Brand expectation } \\
\text { - } & \text { Price value for money } \\
\text { - } & \text { Segmentation }\end{array}$ \\
\hline
\end{tabular}




\begin{tabular}{|c|c|}
\hline & $\begin{array}{ll}\text { - } & \text { Customer expectations } \\
\text { - } & \text { Customer differentiation } \\
\text { - } & \text { Customer delight } \\
\text { - } & \text { CRM }\end{array}$ \\
\hline $\begin{array}{l}\text { Market driven firm } \\
\text { (Q4) }\end{array}$ & $\begin{array}{ll}\text { - } & \text { Market potential } \\
\text { - } & \text { Market orientation } \\
\text { - } & \text { Competitive space } \\
\text { - } & \text { Product competitiveness } \\
\text { - } & \text { New demands of saturated markets } \\
\text { - } & \text { Creating and dominating new markets } \\
\text { - } & \text { Emerging market }\end{array}$ \\
\hline
\end{tabular}

Each driver connects strongly to the nature of the driven firm and is self explanatory.

\section{Learning from Indian Experiences}

The learning from international evidences and outcomes based on variables connected with the nature of the firm (product, customer, and market), can be extended to many firms operating in India. An exhaustive list of firms was studied operating in India and five firms were picked that strongly reflected the drivers to strategy. Detailed case study followed by analysis was undertaken, while each driver to strategy was discovered that associated with a type of firm (product, customer, and market).

Table 5: The Drivers to Strategy in a product driven, customer driven and a market driven firm

\begin{tabular}{|c|c|}
\hline Firm & Drivers to Strategy \\
\hline $\begin{array}{l}\text { SONY } \\
\text { (product driven firm) }\end{array}$ & $\begin{array}{l}\text { - Technology integration } \\
\text { - } \text { Product orientation } \\
\text { - Innovatogy acceptability/adaptability } \\
\text { - After sales } \\
\text { - Brand trust } \\
\text { - Product pricing }\end{array}$ \\
\hline $\begin{array}{l}\text { Yum } \\
\text { (product driven firm) }\end{array}$ & $\begin{array}{l}\text { - } \quad \text { Product segmentation } \\
\text { - } \quad \text { Product positioning } \\
\text { - } \quad \text { Product/brand/business strategy } \\
\text { - } \quad \text { Product differentiation }\end{array}$ \\
\hline
\end{tabular}




\begin{tabular}{|c|c|}
\hline $\begin{array}{l}\text { On mobiles } \\
\text { (product driven firm) }\end{array}$ & $\begin{array}{ll}\text { - } & \text { Zero advertising cost } \\
\text { - } & \text { Product differentiation /uniqueness } \\
\text { - } & \text { Business strategy } \\
\end{array}$ \\
\hline $\begin{array}{l}\text { Maruti Suzuki } \\
\text { (customer driven firm) }\end{array}$ & $\begin{array}{ll}\text { - } & \text { Brand expectation } \\
\text { - } & \text { Customer expectation } \\
\text { - } & \text { Customer delight/ after sales } \\
\text { - } & \text { Price value for money } \\
\text { - } & \text { Purchasing power parity }\end{array}$ \\
\hline $\begin{array}{l}\text { Bata } \\
\text { (market driven) }\end{array}$ & $\begin{array}{l}\text { - } \text { Mass marketing/ mass production } \\
\text { - } \quad \text { Positioning strategy } \\
\text { - } \quad \text { Price value for money } \\
\text { - } \text { Fill the customer expectation(product line) } \\
\text { - } \quad \text { Quick adaptability and response (regarding } \\
\text { market) } \\
\text { - } \quad \text { Diversification } \\
\text { - } \quad \text { Promotional strategy (make a brand) } \\
\text { - Trust sale }\end{array}$ \\
\hline
\end{tabular}

\section{Development of Path Finder Strategy}

"Path Finder Strategy" provides radar to a strategist in ascertaining, which direction the firm is heading to and the path it must go. Each firm, whether a product driven, a customer driven or a market driven (with different combinations), may have to craft a different path suiting its capability. No path is easily replicable and is unique to each firm, thus being the differentiator. The trick is in deeper understanding with the nature of business the firm is engaged into, the product it offers, the customers' it has and desire to create.

\section{Conclusions: Interpreting Path Finder Strategy}

Thus, each firm can craft its own strategy that shall define its "Path Finder Strategy". A typical product driven firm that drives its customers' and markets' has been illustrated as in figure 4. Each quadrant (Q2, Q3 \& Q4) comprises of drivers' to strategy within the subset of the associated quadrant. Certain firms may be driven by few of these variables, while some firms could be driven by most of these variables. Each driver may exhibit a lower or higher orientation within the quadrant based on the strategists' point of view and how he/she intends to drive the firm. The lowest orientation has been kept closer to the epicentre of the radar followed by the highest orientation towards the periphery. By connecting the defined drivers one can visualise the "Path Finder Strategy" for the firm. Hence, each firm will exhibit a unique set of combinations and drivers to its strategy. As the firm progresses in its learning process, this path driven strategy will strongly connect to its 
strategic sustainable development.

Figure 4: The Path Finder Strategy Radar

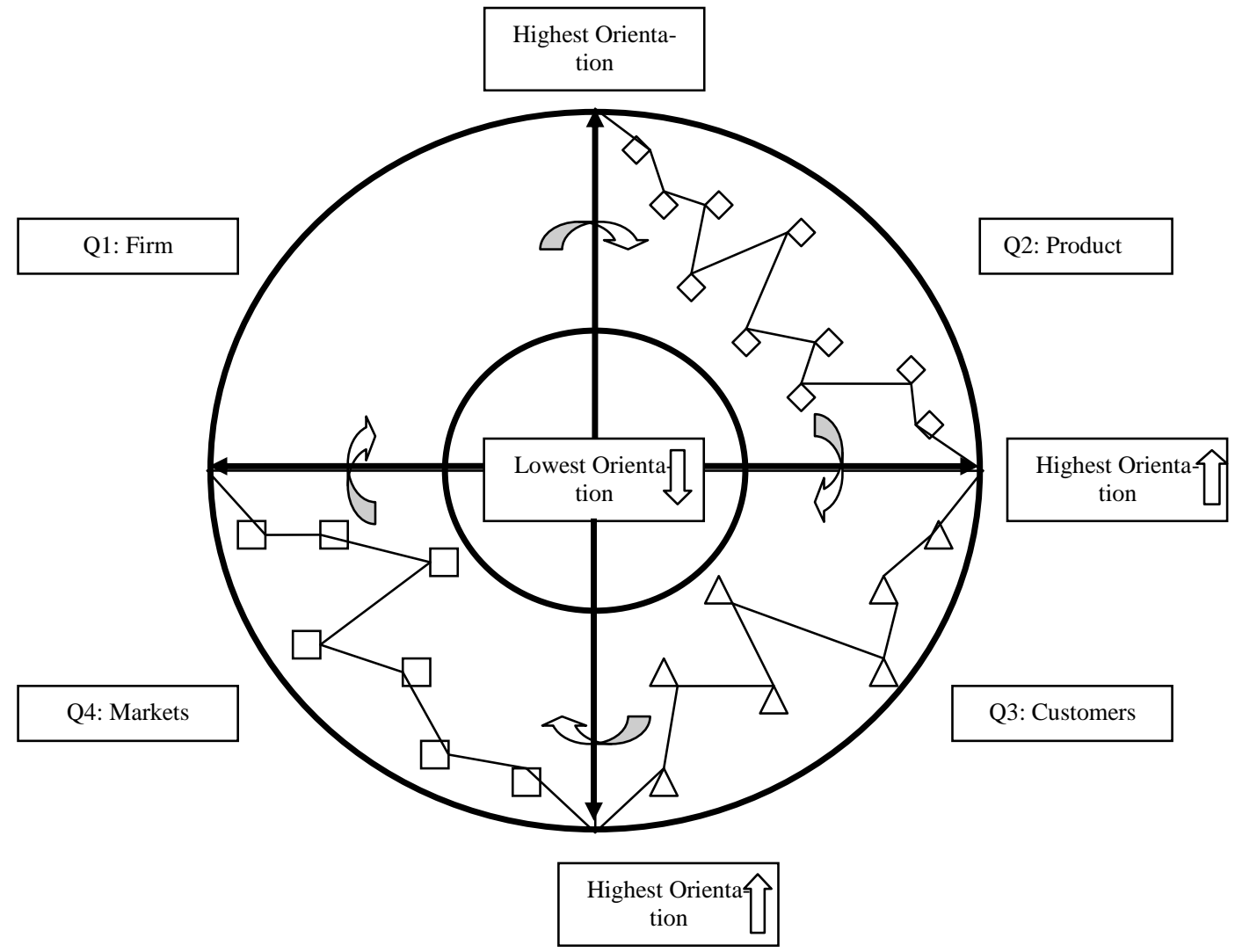

$\diamond \quad$ : Innovation, Integration of Technology, Technology Acceptability \& Adaptability, Product Pricing, Product Segmentation, Product Differentiation, Product Positioning, Brand Trust, Zero Advertising Cost, Product after Sales Services'

$\triangle \quad$ : Brand expectation, Price value for money, Segmentation, Customer expectations, Customer differentiation, Customer delight, CRM

: Market potential, Market orientation, Competitive space, Product competitiveness, and new demands of saturated markets, Creating and dominating new markets, emerging market

\section{Ensuing Research and limitations}

There is a scope for discovering and connecting additional drivers' to strategy associated with each type of firm (product, customer and market). There is a scope for deriving the strategy radar for each type of firm that is product driven, customer 
driven and market driven, as well as linking to the industry it belongs to. The research is confined to Indian Territory and firms operating within India, an emerging market. The scope widens if global firms operating from different geographies could be studied for a more universal learning.

\section{Acknowledgements}

The author is also thankful to Research Scholars, Ms.Gunja Jaiswal, Mr.Himanshu Gupta, Mr.Naveen Singh, Mr.Subhashish Chakraborty and Mr.Subir Bhattacharya for their valuable inputs and research contributions.

\section{References}

1. Andrew, P. J., Haanes, K., Michael, D., Sirkin, H., and Taylor, A. (2009), "Innovation 2009, making hard decisions in the downturn", A BCG senior management survey.

2. Ansoff, H.I. (1965), Corporate Strategy, McGraw-Hill: New York.

3. Brandenburger, A.M., and Nalebuff, B.J. (1995), "The right game: Use game theory to shape strategy," Harvard Business Review, July-August.

4. Brown, S., and Blackmon, K. (2005), "Aligning manufacturing strategy and business-level competitive strategy in new competitive environments: the case for strategic resonance", Journal of Management Studies, Vol. 42, No. 4, pp. 793-815.

5. Corbett, C., and Van, Wassenhove, L. (1993), "Trade-offs? What trade-offs? Competitiveness in manufacturing strategy", California Management Review, Vol. 35, No. 4, pp. 107 122.

6. Drejer, A. (2002), "Strategic Management and Core Competencies: Theory and Application", Quorum Books: Westport, CT.

7. Eisenhardt, K.M., and Martin, L.A. (2000), "Incorporating Sustainable Business Practices into Company Strategy", Business Strategy and the Environment, Vol. 16, No.1, pp. 26-38

8. Fowler, S.J. and Hope, C. (2007), "Incorporating sustainable business practices into company strategy", Business strategy and the Environment, Vol. 16, No.1, pp. 26-38.

9. Ghemawat, P. (1991), "Resources and Strategy: An IO Perspective", Harvard Business School.

10. Hamel G., and Prahalad, C.K. (1994), Competing for the Future. Harvard Business School Press: Boston, MA.

11. Hart, S.L. (1995), "A natural-resource-based view of the firm”, Academy of Management Review, Vol. 20, No. 4, pp. 986.

12. Herbig, P.A., (1994), “The Innovation Matrix: Culture and Structure Prerequisites to Innovation", Quorum Books, Westport, CT.

13. Hitt, Michael, A.; Ireland, R. Duane and Hoskisson, Robert, E., (2006), "Strategic management, competitiveness and globalization", Thomson south western

14. Joshi, M., (2010a), 'Fostering innovation: transition from chimps to hyena and lion type innovative enterprise', World Review of Entrepreneurship, Management and Sustainable Development, Vol. 6, Nos. 1/2, pp.2-16. 
15. Joshi, M., (2010b), 'Embracing competitive renaissance by steering innovation velocity', World Review of Entrepreneurship, Management and Sustainable Development, Vol. 6, Nos. 1/2, pp.149-162.

16. Kay, J., (1995), "Why firms succeed", Oxford university press, Inc., New York, NY.

17. Lafley, A., G., and Charan, Ram, (2008), "The game changer", Crown publishing.

18. Leontiades, M. (1982), "The confusing words of business policy", Academy of Management Review, Vol. 7, No.1, pp-45-48

19. Miller, D. (1982), "The generic strategy trap”, Journal of Business Strategy, Vol. 13, No. 1, p. 37.

20. Mintzberg, H. (1978), "Patterns in Strategy formation”, Management Sciences, Vol. 24, pp. 934-948.

21. Oster, S.M., (1994), "Modern Competitive Analysis", 2nd ed., Oxford University Press, New York

22. Penrose, E.T. (1959), "The theory of the growth of the Firm", Wiley, New York.

23. Porter, M. (1980), Competitive Strategy, Free Press: New York

24. Porter, M. (1985), Competitive Advantage, Free Press: New York

25. Prahalad, C.K., and Hamel, G. (1990), "The core competence of the corporation", Harvard Business Review, May-June: pp. 79-91.

26. Prahlad, C. K. and Krishnan, M.S., (2008), "The new age of innovation", Tata McGrawHill publishing company limited

27. Rogers, E.M. (1983), Diffusions of Innovations, 3rd ed., New York: The Free Press.

28. Shapiro, C. (1989), "The theory of business strategy", RAND journal of Economics, Vol. 20, No. 1, pp. 125-137.

29. Teece, D. (1984), "Economic analysis and strategic management", California Management Review, Vol. 26, No. 3, pp. 87-110.

30. Teece, D., Pisano, G., and Shuen, A. (1997), "Dynamic capabilities and strategic management", Strategic Management Journal, Vol. 18, No. 7, pp. 509-533.

31. Teece, D. (1998), "Capturing value from knowledge assets: the new economy, markets for know-how, and intangible assets", California Management Review, Vol. 40, No. 3, pp. 55 79.

32. Ward, P.T, and Duray, R. (2000), "Manufacturing strategy in context: environment, competitive strategy and manufacturing strategy", Journal of Operations Management, Vol. 18, No. 2, pp. 123-138.

33. Wheelen, T.L, and Hunger, J.D. (1983), Strategic Management and Business Policy, Addison-Wesley: Reading, MA.

34. Yavitz, B., and Newman, W. (1982), Strategy in Action, Free Press: New York, NY.

\section{Websites}

1. Bata (2012) http://www.bata.com/ (accessed on $1^{\text {st }}$ January)

2. Maruti Suzuki (2012) http://www.marutisuzuki.com/ (accessed on $1^{\text {st }}$ January)

3. Yum (2012) http://www.yum.com/ (accessed on $1^{\text {st }}$ January)

4. On Mobile (2012) http://www.onmobile.com/ (accessed on $1^{\text {st }}$ January) 
5. Sony (2012) http://www.sony.net/ (accessed on $1^{\text {st }}$ January)

Manoj JOSHI. Prof Manoj Joshi is into the Editorial Boards' of IJEI, JFBM, JSBM, JCE, WREMSD, BSEVEM, 'Foundations and Trends in Entrepreneurship', 'Amity Business Journal' and several other leading International Peer Reviewed Journals. Case writing is his keen interest, besides mentoring Entrepreneurs and consulting on 'Innovation and Family Business Strategy'. Prior to academics, he had been Head of Business Development and Engineering Design with a leading International Screw Pump / Heat Exchanger Manufacturers' with over 22 years experience. 